Halaman 77-87

\title{
Perbandingan Kemampuan Berpikir Kreatif dengan Penerapan Model Pembelajaran POE (Predict Observe Explain) dan POEW (Predict Observe Explain Write) pada Siswa SMA Negeri 1 Ngemplak Boyolali Tahun Pelajaran 2012/2013
}

\section{Comparison of Creative Thinking Skills on Application of POE (Predict Observe Explain) and POEW (Predict Observe Explain Write) Learning Model on Student at SMA Negeri 1 Ngemplak Boyolali in the Academic Year of 2012/2013}

\author{
Nurul Qomariyah ${ }^{\text {a }}$, Meti Indrowati ${ }^{b}$, Joko Ariyanto $^{c}$ \\ a Pendidikan Biologi FKIP UNS, Email: nurul_qom11@yahoo.com \\ ${ }^{\mathrm{b}}$ Pendidikan Biologi FKIP UNS, Email: metindrowati@yahoo.co.id \\ c Pendidikan Biologi FKIP UNS, Email: joko_ariyanto_30@yahoo.com
}

Diterima 18 Juli 2013, disetujui 15 Desember 2013

\begin{abstract}
The research is aimed to find out the difference of creative thinking skills between application of POE (Predict Observe Explain) and POEW (Predict Observe Explain Write) learning model on student at SMA Negeri 1 Ngemplak Boyolali in academis year 2012/2013. The research belonged to the quasi experiment with research design Posttest Only Non-Equivalent Control Group Design. This research applied POE (Predict Observe Explain) learning model in the experimental group 1 and POEW (Predict Observe Explain Write)learning model in the experimental group 2. Population of research was the students in X degree SMA Negeri 1 Ngemplak Boyolali. The sampling used the cluster sampling was used as samply techniquel. The data collection technique was usedwerw test method belonged test shaped essay (for taking the data of students' creative thinking skills) and non-test method belonged documents method (for taking second data) and observation method (for taking the enforceability of the syntax and measure students` achievement psichomotor and affective as supporting data). Hypothesis testing belonged t-test. The results of the research shows that the mean of student's capability of creative thinking in experiment group 1 higher than experiment group 2, it was 77,35 for experiment group 1 and 70,57 for experiment group 2. The result of hypothesis is analyze by t-test and it gets significant value 0,010 ( $\mathrm{sig}<0,05)$, so there is difference of creative thinking skills between application of POE learning model and POEW learning model. Conclution of the research is there creative thinking skills between class use POE (Predict Observe Explain)learning model different withclass use POEW (Predict Observe Explain Write) learning model on student at SMA Negeri 1 Ngemplak Boyolali in academis year 2012/2013.
\end{abstract}

Key Words: POE (Predict Observe Explain) Learning Model, POEW (Predict Observe Explain Write) Learning Model, Creative Thinking Skills

\section{Pendahuluan}

Target dari pendidikan saat ini adalah untuk menciptakan sumber daya manusia yang berkualitas tinggi dimana manusia yang mempunyai keahlian, mampu bekerja sama, berpikir tingkat tinggi, kreatif, terampil, mampu berkomunikasi dan mampu belajar sepanjang hayat (life-long learning).

Pendidikan pada sekolah dasar, sekolah menengah pertama atau sekolah menengah atas selalu melibatkan proses berpikir. Proses berpikir ditentukan oleh banyak hal, salah satunya adalah kemampuan berpikir manusia. Berpikir 
merupakan proses kognitif untuk memperoleh pengetahuan (Liliasari, 2011).

Kegiatan pembelajaran atau proses pembelajaran merupakan salah satu faktor yang mendukung tercapainya kualitas pendidikan yang tinggi. Kegiatan pembelajaran di sekolah seharusnya dibuat menyenangkan dan semenarik mungkin sehingga siswa tidak merasa bosan dan dapat belajar dengan baik serta hasil pembelajaran yang diperoleh dapat optimal. Pembelajaran yang melibatkan siswa akan membuat siswa itu lebih mengerti dan memahami tentang materi yang disampaikan oleh guru. Pembelajaran yang seperti ini bersifat student center yang berarti pembelajaran terpusat pada siswa dan guru hanya sebagai fasilitator dalam belajar.

Banyak yang menganggap bahwa ilmu pengetahuan terutama biologi merupakan ilmu hafalan. Anggapan ini tidak benar. Ilmu pengetahuan tidak untuk dihafalkan tetapi dipahami. Biasanya kalau siswa itu hanya hafal, maka materi pembelajaran akan cepat dilupakan, namun apabila siswa itu faham, maka materi pembelajaran yang dipelajari akan selalu diingat.

Proses kemampuan berpikir tingkat tinggi antara lain meliputi kemampuan berpikir kritis yang berarti tajam dalam menganalisis dan kreatif yang bersifat daya cipta. Kemampuan berpikir kritis maupun berpikir kreatif merupakan hal penting dan sangat diperlukan siswa untuk memecahkan suatu permasalahan dan juga menghadapi persoalan hidup di masa yang akan datang.

Kemampuan berpikir kreatif di bidang pendidikan, nantinya akan membantu siswa dalam memecahkan suatu masalah yang dihadapi dalam proses belajar. Kemampuan berpikir kreatif pada siswa menjadi hal yang sangat penting karena masalah nyata yang ada di dunia saat ini tidak sederhana dan konvergen. Untuk itu, guru perlu mengembangkan kemampuan berpikir kreatif pada diri siswa (Afidah, 2012).

Kemampuan berpikir kreatif mempunyai beberapa aspek, yaitu: fluency, flexibility, originality, dan elaboration (Munandar, 2009). Rendah atau tingginya kemampuan berpikir kreatif siswa disebabkan oleh banyak faktor, salah satunya adalah model pembelajaran yang digunakan oleh guru dalam proses pembelajaran.

Alternatif model pembelajaran yang akan membuat siswa dapat menemukan, membangun konsep sendiri dan meningkatkan kemampuan berfikir kreatifnya, yaitu model pembelajaran POE (PredictObserveExplain) dan model 
pembelajaran POEW (Predict Observe Explain Write).

Model pembelajaran POE merupakan model pembelajaran dengan menggunakan metode eksperimen yang dimulai dengan penyajian masalah kemudian peserta didik akan diajak untuk memberikan prediksi (dugaan sementara) terhadap kemungkinan yang akan terjadi lalu dilanjutkan dengan observasi (pengamatan langsung) yang dibuktikan dengan melakukan suatu eksperimen atau percobaan untuk menemukan kebenaran dari prediksinya dan akhirnya peserta didik menjelaskan kebenaran atau kesalahan antara hasil pengamatan dengan prediksinya.

Model pembelajaran POE ini akan memaksa siswa untuk berpikir dalam tahap prediksi. Pada tahap ini, siswa dituntut untuk lebih kreatif, sehingga akan menghasilkan ide atau gagasan sementara yang banyak.

Langkah POE yang kedua yaitu siswa melakukan pengamatan langsung (observasi) melalui kegiatan praktikum. Pada tahap ini, siswa akan lebih memahami materi pembelajaran yang diberikan oleh guru karena siswa tersebut melakukan sesuatu untuk membuktikan kebenaran prediksinya.

Langkah POE yang ketiga yaitu siswa berdiskusi dengan temannya mengenai benar atau salah antara prediksi dengan hasil pengamatan yang telah dilakukan. Jadi dengan adanya proses prediksi, observasi dan eksplain ini diharapkan mampu mengembangkan ide atau gagasan dari siswa sehingga siswa tersebut mempunyai kemampuan berpikir kreatif yang tinggi.

Model pembelajaran kedua yang diusulkan adalah model pembelajaran POEW. Model pembelajaran ini merupakan perkembangan dari model pembelajaran POE (Predict, Observe and Explain) dan strategi pembelajaran TTW (Think Talk Write). Model pembelajaran POE seperti yang telah dijelaskan di atas. Sedangkan strategi pembelajaran TTW merupakan strategi pembelajaran yang memfasilitasi latihan berbahasa secara lisan dan menulis dengan lancar. Pada dasarnya strategi ini dibangun mulai berpikir, berbicara dan menulis. Strategi pembelajaran TTW ini dimulai dari keterlibatan siswa dalam berpikir setelah proses membaca lalu berbicara yaitu saling membagi ide dengan temannya. Selanjutnya menuliskan kesimpulannya.

Model pembelajaran POEW memungkinkan siswa lebih aktif dalam proses pembelajaran dimana guru akan memberikan kesempatan kepada siswanya untuk mengkonstruksi pengetahuannya, mengkomunikasikan apa yang ada di pikirannya dan menuliskan hasil diskusi dengan kata- 
katanya sendiri sehingga siswa akan lebih memahami konsep materi yang diajarkan. Hal ini diharapkan kemampuan berpikir kreatif siswa akan lebih meningkat.

Menulis merupakan alat yang bermanfaat dari berpikir karena dari proses berpikir inilah siswa akan memperoleh pengalaman sebagai suatu aktivitas yang kreatif. Salah satu manfaat dari menulis yaitu dapat meningkatkan taraf berpikir siswa ke arah yang lebih tinggi (higher order thinking). Keuntungan lain dari proses menulis yaitu dapat membantu siswa untuk memfokuskan pada konsep-konsep kunci dalam suatu materi pelajaran, menilai pemahaman dan memudahkan retensi (Ansari, 2003). Menurut Manzo (1995), keuntungan yang diperoleh dari aktivitas menulis yaitu dengan menulis dapat mengaktifkan pengetahuan awal siswa, meningkatkan intelektual siswa dan membantu merumuskan pandangan siswa. Berdasarkan penjelasan tersebut, dengan adanya proses menulis diharapkan mampu meningkatkan kemampuan berpikir kreatif siswa.

Tujuan penelitian ini adalah untuk mengetahui ada tidaknya perbedaan kemampuan berfikir kreatif antara penerapan model pembelajaran POE (Predict Observe Explain) dan model pembelajaran POEW (Predict Observe
Explain Write) pada siswa SMA Negeri 1 Ngemplak Boyolali Tahun Pelajaran 2012/2013

\section{Metodologi Penelitian}

Penelitian dilaksanakan di SMA Negeri 1 Ngemplak Boyolali pada semester genap tahun pelajaran 2012/2013. Penelitian ini termasuk kuasi eksperimen dengan menggunakan desain penelitian Posttest Only Nonequivalent Control Group Design dengan menggunakan kelompok eksperimen 1 (penerapan model pembelajaran POE) dan eksperimen 2 (penerapan model pembelajaran POEW).

Populasi dalam penelitian ini adalah seluruh siswa kelas X SMA N 1 Ngemplak Boyolali. Teknik pengambilan sampel dengan cluster sampling. Hasil pemilihan sampel menetapkan kelas X1 dengan jumlah siswa 28 orang sebagai kelompok eksperimen 1 yang menerapkan model pembelajaran POE. Kelas X2 dengan jumlah siswa 26 orang sebagai kelompok eksperimen 2 yang menerapkan model pembelajaran POEW.

Variabel bebas dalam penelitian ini adalah model pembelajaran aktif POE dan POEW. Variabel terikatnya adalah kemampuan berpikir kreatif. Materi pembelajaran yang digunakan adalah pencemaran lingkungan. Teknik pengumpulan data yang digunakan dalam 
penelitian ini adalah tes, dokumentasi dan observasi. Dokumentasi pada penelitian ini berupa dokumen nilai UAS semester 1 yang digunakan untuk mengetahui keseimbangan kemampuan awal siswa. Metode tes digunakan untuk mengambil data kemampuan berpikir kreatif siswa. Metode observasi dalam penelitian ini digunakan untuk melihat keterlaksanaan model pembelajaran POE dan POEW. Metode observasi juga untuk mengukur hasil belajar ranah psikomotor dan afektif, namun data ini hanya digunakan sebagai data pelengkap proses belajar mengajar yang meliputi ranah psikomotor dan afektif.

Tes uji coba instrumen penelitian dilakukan untuk mengetahui validitas produk moment dan reliabilitas soal tes kemampuan berpikir kreatif.Selain validasi produk moment, instrumen juga divalidasi konstruk oleh ahli.

Analisis data pada penelitian dengan menggunakan uji t. Sebelum dilakukan analisis data, maka dilakukan uji prasyarat yaitu uji normalitas menggunakan uji Komolgorof-Smirnov dan uji homogenitas dengan uji Levene's.

\section{Hasil dan Pembahasan}

\section{Kemampuan berpikir kreatif}

Hasil analisis ada tidaknya perbedaan kemampuan berpikir kreatif dengan penerapan model pembelajaran
POE (Predict Observe Explain) dan POEW (Predict Observe Explain Write) ditunjukkan pada Tabel 1.

Tabel 1. Hasil Uji-t Perbedaan Kemampuan Berpikir Kreatif dengan Penerapan Model Pembelajaran POE (Predict Observe Explain) dan POEW (Predict Observe Explain Write)

\begin{tabular}{|c|c|c|c|c|c|}
\hline $\begin{array}{l}\text { Variabe } \\
\text { l }\end{array}$ & $\mathbf{t}_{\text {hitung }}$ & Df & Sig & $t_{\text {tabel }}$ & $\begin{array}{l}\text { Kepu } \\
\text { tusan }\end{array}$ \\
\hline $\begin{array}{l}\text { Kemam } \\
\text { puan } \\
\text { Berpikir } \\
\text { Kreatif } \\
\end{array}$ & 2,676 & 52 & 0,01 & 1.675 & $\begin{array}{l}\mathrm{H}_{0} \\
\text { ditola } \\
\mathrm{k}\end{array}$ \\
\hline
\end{tabular}

Hasil keputusan uji menunjukkan Sig $>0,050$ dan $t_{\text {hitung }}<t_{\text {tabel }}$ sehingga $\mathrm{H} 0$ ditolak.Berdasarkan Tabel 1 diperoleh keputusan terdapat perbedaan kemampuan berpikir kreatif antara penerapan model pembelajaran POE dan POEW.

Perbandingan rata-rata nilai untuk setiap aspek kemampuan berpikir kreatif pada kelompok eksperimen 1 dan eksperimen 2 dapat dilihat pada Gambar 1.

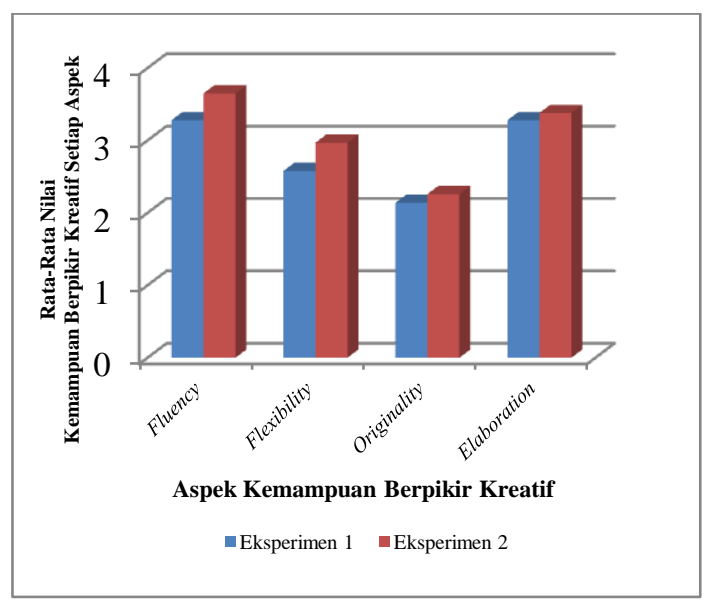

Gambar 1. Perbandingan Rata-Rata Nilai Kemampuan Berpikir Kreatif Setiap Aspek 
Gambar 1 menunjukkan bahwa rata-rata nilai kemampuan berpikir kreatif siswa untuk setiap aspek pada kelompok eksperimen 2 lebih tinggi daripada kelompok eksperimen 1. Kemampuan berpikir kreatif kelompok eksperimen 2 pada aspek fluency sebesar 3,65 sedangkan kelompok eksperimen 1 sebesar 3,28.Nilai aspek flexibility pada kelompok eksperimen 2 yaitu 2,97 yang lebih tinggi daripada kelompok eksperimen 1 yaitu 2,58. Nilai aspek originality kelompok eksperimen 2 sebesar 2,26 sedangkan kelompok eksperimen 1 sebesar 2,14. Pada aspek elaboration, nilai kelompok eksperimen 2 mencapai 3,38 dan kelompok eksperimen 1 mencapai 3,28. Rata-rata aspek kemampuan berpikir kreatif tertinggi pada kelompok eksperimen 2 terletak pada aspek fluency, sedangkan pada kelompok eksperimen 1 terletak pada aspek fluency dan elaboration. Rata-rata aspek kemampuan berpikir kreatif terendah baik pada kelompok eksperimen 2 maupun kelompok eksperimen 1 terletak pada originality. Berdasarkan selisih rata-rata kemampuan berpikir kreatif antara kelompok eksperimen 2 dengan kelompok eksperimen 1 untuk setiap aspeknya, urutan dari selisih terbesar ke yang terkecil adalah flexibility sebesar 0,39 , fluency sebesar 0,37 , originality sebesar 0,12 , dan elaboration sebesar 0,10. Berdasarkan Gambar 1 menunjukkan bahwa terdapat perbedaan kemampuan berpikir kreatif dengan penerapan model pembelajaran POEW dan POE.

Penerapan kedua model pembelajaran tersebut pada materi pencemaran lingkungan memberikan kesempatan yang luas kepada siswa untuk berperan aktif dalam kegiatan pembelajaran. Suyanto (2012) menyatakan bahwa pembelajaran POE yang berbasis laboratorium dan penyelidikan dapat memberikan kesempatan kepada siswa untuk mengembangkan kemampuan berpikirnya. Sementara pada pembelajaran POEW, kegiatan menulis dapat merangsang aktivitas berpikir sehingga dapat mempertinggi pengetahuan dan meningkatkan kemampuan berpikir (Samosir, 2012).

Menurut Munandar (2009), kemampuan berpikir kreatif meliputi 4 aspek, yaitu fluency (kelancaran), flexibility (keluwesan), originality (keaslian) dan elaboration (kemampuan merinci). Adapun penjelasan tiap aspek adalah sebagai berikut.

Aspek yang pertama yaitu fluency. Fluency (kelancaran) merupakan kemampuan dalam mencetuskan banyak gagasan, jawaban atau penyelesaian masalah, memberikan banyak cara atau saran untuk melakukan berbagai hal dan 
selalu memikirkan lebih dari satu jawaban. Aspek fluency pada proses pembelajaran muncul pada tahap predict, explain dan write. Aspek fluency (kelancaran) pada tahap predict terlihat dari banyaknya gagasan siswa yang tercetus dalam merancang percobaan. Aspek fluency (kelancaran) pada tahap explain terlihat saat siswa mampu memberikan banyak gagasan untuk pertanyaan dan kasus yang didapatkan melalui kegiatan diskusi. Pada tahap write, aspek fluency terlihat pada hasil tulisan siswa yang menuliskan rangkuman mengenai materi pencemaran lingkungan.

Aspek yang kedua yaitu flexibility. Flexibility (keluwesan) merupakan kemampuan dalam menghasilkan gagasan, jawaban atau pertanyaan yang bervariasi dengan melihat suatu permasalahan dari sudut pandang yang berbeda. Aspek flexibility nampak pada tahap predict, explain dan write. Aspek flexibility (keluwesan) terlihat dari kegiatan predict, yaitu siswa mampu memberikan macam-macam penafsiran terhadap suatu masalah. Aspek flexibility (keluwesan) pada tahap explain terlihat siswa memberikan macam-macam penafsiran (interpretasi) terhadap data pengamatan yang mereka dapatkan. Pada saat kegiatan diskusi, siswa juga diminta mengelompokkan gambar mengenai penyebab dan dampak pencemaran lingkungan. Aspek flexibility (keluwesan) pada tahap write muncul pada hasil rangkuman terhadap materi pencemaran lingkungan. Masing-masing siswa memberikan bermacam-macam penafsiran mengenai materi pencemaran lingkungan karena pandangan mereka terhadap suatu materi berbeda-beda walaupun inti dari rangkuman mereka itu sama.

Aspek yang ketiga yaitu aspek originality. Originality (keaslian) merupakan kemampuan dalam melahirkan ungkapan yang baru dan unik serta memikirkan cara yang tidak lazim untuk mengungkapkan gagasannya. Aspek originality muncul pada tahap predict, explain dan write. Tahap predict menunjukkan aspek originality (keaslian), dimana siswa mampu merancang percobaan yang sesuai dengan kreasi mereka sendiri. Gagasangagasan yang diungkapkan oleh setiap siswa pada saat kegiatan diskusi merupakan gagasan mereka sendiri, sehingga gagasan tersebut merupakan ide dari setiap siswa yang berbeda dengan siswa yang lain. Hal ini mencerminkan kemampuan originality (keaslian) siswa berkembang melalui pengungkapan gagasan lewat kegiatan diskusi maupun presentasi pada tahap explain. Aspek originality (keaslian) juga muncul pada 
tahap write. Hal ini terlihat pada hasil tulisan siswa.Hasil tulisan siswa berasal dari pemikiran siswa sendiri, sehingga terlihat bahwa hasil tulisan dari masingmasing siswa itu berbeda-beda sesuai dengan bahasa tulisan siswa yang khas.

Aspek yang keempat yaitu aspek elaboration. Elaboration (kemampuan merinci) merupakan kemampuan dalam memperkaya dan mengembangkan gagasan atau produk dan menambah atau merinci detail-detail dari suatu objek, gagasan, atau situasi. Aspek elaboration muncul pada tahap predict, observe dan write. Aspek elaboration pada tahap predict terlihat pada saat siswa menyusun alat dan bahan yang telah dipilih menjadi suatu rangkaian percobaan pengaruh polutan terhadap makhluk hidup. Pada kegiatan observe, mampu mengembangkan aspek elaboration (kemampuan merinci), yaitu siswa melakukan percobaan dengan langkah-langkah terperinci yang sesuai dengan rancangan percobaan yang sudah disusun sebelumnya untuk mencari kebenaran mengenai prediksi (hipotesis) dari rumusan permasalahan pencemaran lingkungan. Selain itu, aspek elaboration (kemampuan merinci) juga muncul pada tahap write. Aspek ini terlihat dari hasil tulisan siswa yang mampu mengembangkan gagasan orang lain yang muncul pada analisis hasil percobaan yang telah dilakukan oleh siswa.

Proses pembelajaran pada kedua kelas eksperimen membuat siswa untuk aktif karena siswa lebih mendominasi dalam kegiatan pembelajaran. Pada proses pembelajaran ini, guru hanya berperan sebagai fasilitator. Pembelajaran dengan penerapan POE dan POEW ini membuat siswa harus menemukan sendiri pemecahan masalah dengan ide-ide yang ada di dalam pikiran siswa sehingga siswa benar-benar dapat memahami dan menerapkan pengetahuan. Pembelajaran yang seperti ini sejalan dengan teori konstruktivisme (Trianto, 2010).

Siswa secara aktif mengkontruksi sendiri pemahamannya selama proses pembelajaran berlangsung. Pemecahan masalah dalam kegiatan diskusi dilakukan melalui interaksi (berkomunikasi) dengan temannya. Pembelajaran POE dan POEW yang memberikan kesempatan siswa mengkonstruksi sendiri pemahamannya sejalan dengan teori belajar Piaget.

Model pembelajaran POE dan POEW ini membuat siswa untuk menemukan kembali informasi dan selanjutnya dikaitkan dengan pengetahuan yang sudah dimiliki siswa untuk memecahkan masalah sejalan dengan teori Ausebel. Kegiatan yang dilakukan oleh siswa merupakan 
pembelajaran yang bermakna. Siswa didorong untuk mengumpulkan informasi dan melakukan percobaan untuk mendapatkan penjelasan dan pemecahan masalah (Trianto, 2010).Pengetahuan yang dimiliki oleh siswa dikaitkan dengan informasi baru yang ditemukan dalam kegiatan percobaan pencemaran lingkungan.

Pembelajaran POE dan POEW yang dilakukan secara berkelompok memberikan kesempatan pada siswa untuk saling bertukar pikiran dan mentransfer pengetahuan dari siswa yang lebih paham kepada siswa yang belum paham. Kegiatan pembelajaran pada kedua kelompok eksperimen dilakukan dengan membagi siswa dalam kelompokkelompok yang bersifat heterogen (Rusman, 2012); berdasarkan jenis kelamin dan kemampuan siswa. Pembelajaran secara berkelompok ini memiliki tujuan agar siswa dapat saling membantu dalam pencapaian tujuan belajar. Kegiatan pembelajaran secara berkelompok mampu memunculkan scaffolding dan interaksi sosial. Scaffolding merupakan suatu proses untuk membantu siswa menuntaskan masalah dengan bantuan orang lainyang memiliki kemampuan lebih daripada dirinya (Rusman, 2012).

Perbedaan kemampuan berpikir kreatif pada dua perlakuan model pembelajaran tersebut karena pembelajaran POEW membuat siswa untuk lebih memahami materi pencemaran lingkungan dengan baik dan berdampak pada kemampuan berpikir kreatif yang semakin baik. Hal ini dikarenakan adanya tahapan write. Shield \& Swinson (Samosir, 2010) menyatakan bahwa menulis dapat membantu merealisasikan salah satu tujuan pembelajaran, yaitu pemahaman siswa mengenai materi yang dipelajarinya. Selain itu, menulis juga dapat merangsang aktivitas berpikir sehingga dapat mempertinggi pengetahuan dan meningkatkan kemampuan berpikir.

$$
\text { Menurut Manzo }
$$

keuntungan yang diperoleh dari aktivitas menulis yaitu dengan menulis dapat mengaktifkan pengetahuan awal siswa, meningkatkan intelektual siswa dan membantu merumuskan pandangan siswa. Dengan adanya kegiatan menulis ini, siswa akan lebih memahami materi yang disampaikan sehingga dia akan mudah mengingat materi tersebut. Selain itu, pemikiran siswa lancar dengan menuliskan pemikirannya.

Penelitian yang dilakukan oleh Suyanto, et al. (2012) menyatakan bahwa pembelajaran POE lebih efektif untuk meningkatkan kemampuan berpikir kritis dan kreatif siswa. Penelitian Samosir (2010) bahwa pembelajaran POEW dapat 
meningkatkan penguasaan konsep dan keterampilan berpikir kritis siswa.

Berdasarkan hasil penelitian dan beberapa penelitian yang relevan menunjukkan bahwa penerapan model pembelajaran POE dan POEW dalam pembelajaran biologi dapat meningkatkan kemampuan berpikir kreatif siswa. Tahapan-tahapan dalam model pembelajaran POE dan POEWdapat meningkatkan berpikir kreatif siswa, pemahaman siswa dan kemandirian belajar (self-directed) dengan mendorong siswa untuk memiliki kecakapan berpikir, aktif mengemukakan gagasan, berkolaborasi dalam kelompok dan menghasilkan ide-ide yang cemerlang. Penerapan model POE pada kelompok eksperimen 1 dan model POEW pada kelompok eksperimen 2 dalam proses pembelajaran akan membekali siswa agar siap menghadapi masalah dengan kemampuan berpikir kreatif yang dimiliki. Model pembelajaran POE dan POEW terbukti mampu meningkatkan kemampuan berpikir kreatif siswa.

Kesimpulan

Berdasarkan hasil penelitian tentang perbandingan kemampuan berpikir kreatif siswa dengan penerapan model pembelajaran POE (Predict Observe Explain) dan POEW (Predict Observe Explain Write) dapat disimpulkan bahwa ada perbedaan kemampuan berpikir kreatif dengan penerapan model pembelajaran POE (Predict Observe Explain) dan POEW (Predict Observe Explain Write) pada siswa SMA Negeri 1 Ngemplak Boyolali Tahun Pelajaran 2012/2013.

\section{Daftar Pustaka}

Afidah, N. I. (2012). Pengaruh Penerapan Metode Socratic Circles Disertai Media Gambar Terhadap Kemampuan Berpikir Kreatif Siswa. Skripsi tidak dipublikasikan. Surakarta: Universitas Sebelas Maret.

Ansari, B. I. (2003). Menumbuh kembangkan Kemampuan Pemahaman dan Komunikasi Matematik Siswa SMU melalui Strategi Think Talk Write. Disertasi tidak dipublikasikan. Bandung: Universitas Pendidikan Indonesia.

Liliasari. (2011). Peningkatan Kualitas Guru Sains Melalui Pengembangan Keterampilan Berpikir Tingkat Tinggi. Seminar Nasional Pasca Sarjana. Bandung: UPI

Manzo, A. (2002). Higher-order Thinking Strategies for the Classroom. http://members.aol.com/MattT10574/ HigherOrderLiteracy.htm [20/6/ 2013] Munandar, U. (2009). Pengembangan Kreativitas Anak Berbakat. Jakarta: PT Rineka Cipta

Rusman. (2012). Model-Model Pembelajaran. Jakarta: Rajagrafindo Persada

Samosir, H. (2010). Model Pembelajaran Predict Observe Explain Write (POEW) untuk Meningkatkan Penguasaan Konsep Kalor dan Keterampilan Berpikir Kritis Siswa. Thesis tidak dipublikasikan. Bandung: Universitas Pendidikan Indonesia.

Suyanto, Y.P., Susanto, H., \& Linuwih, S. (2012). Kefektifan Penggunaan Strategi Predict, Observe and Explain untuk Meningkatkan Kemampuan 
Qomariyah, N., et al. - Perbandingan Kemampuan Berpikir Kreatif.....

Berpikir Kritis dan Kreatif Siswa.Unnes Physics Education Journal. Mei 2012, 15-25
Trianto. (2010). Mendesain Model Pembelajaran Inovatif-Progresif. Jakarta: Prenada Media 